\title{
RECRUTAMENTO E PERFIL DOS CANDIDATOS E DOS ELEITOS À CÂMARA DOS DEPUTADOS NAS ELEIÇÕES DE 2006*
}

\section{Maria do Socorro Sousa Braga Luciana Fernandes Veiga Angel Miríade}

\section{Introdução}

Segundo a literatura especializada em partidos políticos, uma de suas principais funções no processo democrático é a seleção de candidatos

* Uma versão preliminar deste artigo foi apresentada no XXXI Anual da Anpocs realizada em Caxambu, em outubro de 2006. Aproveitamos para agradecer os comentários e sugestões tanto dos colegas que participaram conosco do ST Partidos e Sistemas Partidários naquela Anpocs quanto aos pareceristas da revista RBCS. O material empírico deste artigo faz parte dos seguintes projetos de pesquisa "Partidos Políticos: Organização, Recrutamento Político e Representação", desenvolvido no Departamento de Ciências Sociais da Universidade Federal de São Carlos, com financiamento da Fapesp e do Banco de dados "Eleições 2006: candidatos ao Poder Legislativo no Brasil" do Núcleo de Pesquisa em Sociologia Política Brasileira - UFPR.

Artigo recebido em agosto/2008

Aprovado em fevereiro/2009 a cargos eletivos. De acordo com alguns autores, a importância dessa atividade partidária decorre de dois fatores: primeiro, é a chave do processo de recrutamento político em uma democracia representativa. Segundo, é um dos momentos mais significativos no que concerne aos conflitos intrapartidários. O processo de seleção revela muito sobre a disputa interna, de que forma ela se dá, com que intensidade e como é resolvida (Schattschneider, 1941; Gallagher e Marsh, 1988; Katz, 2001). Isto é, permite examinar a dinâmica interna de uma organização partidária. Por isso mesmo, outros autores afirmam que a questão da designação dos candidatos é um elemento essencial em qualquer definição de partido político (Key, 1964; Sartori, 1976; Schelesinger, 1991).

Além disso, os métodos usados para selecionar afetam tanto os tipos de postulantes que serão eleitos como o comportamento deles na Câmara dos 
Deputados (Gallagher e Marsh, 1988; Carey e Shugart, 1995). Mas o processo de seleção é um dos momentos centrais da vida partidária porque, sobretudo, permite conhecer o funcionamento interno dos partidos e, o mais importante, identificar a estrutura de autoridade da organização partidária (Katz e Mair, 1995; Ranney, 1965; Schattschneider, 1941).

Considerando esses pressupostos, este artigo investiga o recrutamento e o perfil dos candidatos e dos eleitos à Câmara dos Deputados nas eleições de 2006. Para o encaminhamento desta investigação, o texto foi estruturado em três partes. Além da introdução, próxima seção discute a literatura pertinente, buscando a relação possível entre organização partidária, recrutamento político e democracia representativa. A terceira seção examina o processo de seleção dos candidatos a deputado federal realizado pelos partidos PP, PFL (DEM), PMDB, PSDB e PT. Por fim, a quarta e última seção analisa o perfil social dos candidatos e dos eleitos, relacionando-o com as dimensões identificadas no processo de seleção levado a cabo pelas lideranças partidárias.

\section{Dimensões teóricas e o debate no Brasil}

Quase todas as discussões sobre partidos políticos no país podem ser classificadas em dois eixos: existem os estudos que primam pela importância dos partidos nos diversos procedimentos da democracia e aqueles que não reconhecem tal importância. Isso acontece quando se trata de estudos sobre comportamento do eleitor e sobre comportamento parlamentar. Quando o tema é recrutamento e escolha de candidatos, ocorre a mesma polarização.

De um lado, há o argumento da fragilidade da autoridade dos partidos na definição das candidaturas (Mainwaring, 1991). Afinada com essa linha, tem-se a teoria da prática do self-recruitment, em que a coordenação intrapartidária sobre as candidaturas seria geralmente fraca, levando inclusive a resultados eleitorais imprevistos.

Mainwaring (1992) supõe que o controle das lideranças sobre o processo de seleção e formação da lista de candidatos é fraco quando comparados aos partidos europeus. Tal dedução baseia-se na observação das regras do sistema eleitoral e na su- posta natureza descentralizada do processo de seleção dos candidatos a cargos eletivos. No que diz respeito à variável institucional, isso ocorreria em função de dois elementos do sistema eleitoral: a) adoção da lista partidária aberta, que estimularia o individualismo nas campanhas eleitorais em detrimento de estratégias partidárias coletivistas; e b) uso do dispositivo da candidatura nata, vigente até as eleições municipais de 2000.

Esta linha de raciocínio é compartilhada por uma parte expressiva da literatura especializada que adota a perspectiva institucionalista para explicar os fenômenos partidários. Segundo esses teóricos, a influência do partido no processo de seleção de candidatos varia conforme o tipo de sistema eleitoral e a estrutura de autoridade partidária (Duverger, 1970; Mainwaring, 1991; Katz, 2001; Rahat e Hazan, 2001). O argumento é o de que em sistema eleitoral proporcional com lista fechada os partidos têm pleno controle sobre esse processo, pois além de escolherem os candidatos que vão disputar as cadeiras parlamentares por sua legenda também ordenam previamente a lista de candidatos. Já a combinação de representação proporcional com lista aberta, por aumentar a influência dos eleitores na seleção dos candidatos, diminuiria o controle das lideranças partidárias sobre o processo de indicação.

No entanto, a realidade mostra que também em sistemas proporcionais de lista fechada os seletores se demonstram bastante vulneráveis quanto à tomada de decisão e aos apelos das demandas eleitorais. De fato, independentemente de qual seja o sistema, o objetivo final é angariar votos e, portanto, candidatos com apelo eleitoral são sempre bemvindos, incentivam e mesmo constrangem para a sua aceitação.

É o caso, por exemplo, da análise de Norris e Lovenduski (1995), que se estrutura a partir das noções de oferta de candidaturas e demandas dos selecionadores que, em última instância, refletem as expectativas do mercado eleitoral. Os autores mostram que os partidos são suscetíveis a demandas eleitorais também em sistemas proporcionais de lista fechada, pois tais demandas pressionam os selecionadores na hora da tomada de decisão sobre as candidaturas.

Tendo em mente esse quadro, nosso argumento não visa a invalidar a proposição de Mainwa- 
ring, mas apenas a complementá-la, delimitá-la, enfatizando que o sistema proporcional com lista fechada não resguarda os seletores do apelo eleitoral apresentado por alguns candidatos. Ou seja, ainda que eles tenham mais controle, e isso é inegável, também são suscetíveis e constrangidos em suas decisões pelos candidatos "puxadores de voto".

Outra conclusão que a colocação de Mainwaring pode suscitar, e para a qual é conveniente alertar, refere-se à suposição de que em um sistema de lista aberta, no caso específico do Brasil, o partido não teria controle na escolha. Os dados deste trabalho mostram como no processo de seleção de candidaturas se dá o controle das lideranças locais e a participação das lideranças nacionais. No Brasil, o número de candidatos em geral não chega a superar o número de vagas nas listas partidárias. Ou seja, não se tem um processo de seleção muito competitivo. A competição acontece de verdade na distribuição de recursos de campanha. Vale ainda lembrar que no Brasil o Horário Gratuito de Propaganda Eleitoral é distribuído para os partidos que dividem o tempo de exposição na TV entre os seus candidatos. Nota-se que alguns candidatos são privilegiados com mais tempo do que outros, e quem define tal distribuição são os líderes partidários. Reiterando, não nos contrapomos ao argumento que endossa o peso das instituições, com o qual concordamos em muitos ângulos, mas apenas desejamos chamar a atenção para o fato de que existem muitas questões entre as premissas institucionais e suas conclusões.

Ainda no que tange à estrutura de autoridade partidária, uma outra suposição é a de que enquanto nos partidos centralizados as lideranças nacionais têm mais peso no processo de seleção dos candidatos, controlando o acesso à lista, nos partidos com estrutura descentralizada as decisões seriam tomadas na esfera local e as lideranças não deteriam o controle das indicações, o que implicaria maior esforço individual dos postulantes para figurar na lista partidária (Duverger, 1970; Carey e Shugart, 1995). Em conseqüência, esperar-se-iam vínculos mais frouxos entre partido e deputados na Câmara, redundando em fraca coesão e disciplina parlamentar.

No Brasil o diagnóstico predominante, de acordo com essa visão, é de que, excetuando-se os par- tidos de esquerda, os demais apresentam organizações nacionais muito fracas, prevalecendo o poder decisório nas instâncias estaduais. Segundo Mainwaring (2001, p. 309), a irrelevância das organizações partidárias nacionais na escolha de candidatos tem, como conseqüência, partidos de tipo catch-all com bancadas ideologicamente heterogêneas e dirigentes nacionais com pouco poder sobre os parlamentares, o que leva a uma baixa disciplina parlamentar. Assim sendo, o Brasil apresentaria uma combinação desfavorável à criação de partidos políticos nacionais fortes: representação proporcional com lista aberta e estrutura organizacional descentralizada. A principal conseqüência disso seria a conformação de partidos inconsistentes programaticamente e com débil controle sobre as principais decisões partidárias no que se refere à dinâmica de representação.

No entanto, não nos parece evidente que, em vista dos incentivos gerados pela lógica de funcionamento da representação proporcional com listas abertas, os candidatos (e eleitos) mantenham deliberadamente vínculos frouxos com seus partidos visando a constituir uma reputação pessoal em detrimento de uma ação coletiva propiciadora da sobrevivência da organização partidária.

Para que o argumento funcione é preciso demonstrar a validade da premissa segundo a qual os partidos buscam sua "estabilidade organizativa", isto é, procuram manter uma linha de autoridade no seu interior. Esta linha de ação, por sua vez, é defendida pela coalizão dominante, conformada por dirigentes partidários e parlamentares fundadores (ou comprometidos com a continuidade da organização) do partido.

Segundo estudiosos da teoria da organização, particularmente Ângelo Panebianco (1992), a chave para o sucesso da estabilidade organizativa de um partido repousa na distribuição, pela coalizão dominante, de incentivos coletivos e seletivos para os membros partidários. Para isso, a coalizão dominante, isto é, a elite dirigente do partido, precisa ter o controle dos recursos vitais para os partidos.

Esses recursos são chamados, por Panebianco, de "zonas de incerteza", constituídas pelos seguintes aspectos: competência (saber especializado no manejo das relações político-organizativas internas e externas ao partido); relações com o ambiente externo; 
comunicação interna; controle das regras organizativas; fontes de financiamento e recrutamento político.

Embora Panebianco ressalte o caráter cumulativo desses recursos para que haja estabilidade organizacional, a verificação de todos esses aspectos requer uma ampla agenda de pesquisa. Para dar conta da preocupação central deste artigo, que é o exame do papel dos partidos na seleção dos operadores da representação e do seu controle sobre a formação da lista partidária ao Legislativo federal, será focado unicamente o recrutamento político. A esta "zona de incerteza" acrescentamos uma outra: controle sobre o acesso à lista partidária.

Supomos que, apesar de o nosso sistema de representação ser proporcional com lista aberta, o que teoricamente possibilita ao eleitorado a sua ordenação, na prática os dirigentes partidários, ao manterem o controle tanto sobre o processo de seleção dos candidatos e o acesso à lista como sobre recursos partidários importantes (especialmente o fundo partidário e o tempo no horário gratuito no rádio e na TV), acabam realizando uma ordenação informal dos candidatos. Assim, ao contrário do que sustenta a literatura sobre os partidos políticos brasileiros, outro argumento defendido neste artigo é o de que por meio do controle do processo de seleção de candidatos e da ordenação informal da lista partidária os partidos brasileiros vêm tendo um papel fundamental na dinâmica de formação de uma elite política responsável por operar a representação política. Esse controle, por sua vez, é feito de maneira bastante concentrada, conforme mostra o modelo de organização partidária examinado.

De fato, este artigo visa mais a combater os excessos que o argumento predominante a respeito do recrutamento partidário brasileiro pode suscitar do que propor uma abordagem radicalmente contrária.

Dispostas a entender como funciona o recrutamento dentro dos partidos, Braga (2008) e Álvares (2006) analisaram os estatutos partidários no Brasil a partir do modelo de inclusão e exclusão adotado por Rahat e Hazan (2001). Para ele o processo de recrutamento pode ser mais inclusivo ou mais exclusivo, dependendo principalmente dos critérios estipulados para que o cidadão possa apresentar-se como candidato e do órgão que irá selecionar as candidaturas, o selectorate. No que se refere à candidatura, no pólo da inclusividade, todo cidadão eleitor poderia ser candidato, e no pólo da exclusividade encontra-se uma série de restrições para a apresentação da candidatura, como analisa o autor a respeito do Partido Socialista Belga e suas muitas exigências. No que se refere ao selectore, no pólo da inclusividade, as eleições seriam abertas e gerais para a definição das candidaturas, e no pólo da exclusividade seria o caso de apenas um líder partidário escolher a lista.

Braga e Álvares apontam que o PT é o único partido que contém um item específico determinando os pré-requisitos para um filiado ser candidato. Todos os demais partidos utilizam-se formalmente apenas da legislação eleitoral que controla a idade mínima para a candidatura aos diversos cargos e o tempo mínimo de filiação partidária necessário. Já no tocante ao selectorate, embora os estatutos abordem pontualmente o tema, Álvares (2006) observou um evidente predomínio da patronagem da liderança. Tem-se aí uma forte atuação de regras informais.

A respeito de como as regras de seleção influenciam o perfil dos selecionados, Hazan chegou a duas generalizações:

[...] os tipos de candidatos que são produzidos pelos vários métodos de seleção de candidatos: os que têm as melhores e as piores chances para serem escolhido. Entre os primeiros, encontram-se os que buscam reeleição, do sexo masculino (titulares que já têm um perfil diferente dos aspirantes porque já se acham no ambiente político e podem ser re-selecionados); e entre os segundos, estão as mulheres, que já entram no sistema de seleção em desequilíbrio, daí se submetendo à descentralização incorporada - sistema de cotas (apud Álvares, 2006, p. 10).

Em suma, buscamos apresentar como os partidos brasileiros realizam a sua seleção de candidaturas, demonstrando a maneira pela qual as elites partidárias controlam o processo. Além disso, mostrar-se-á como as esferas locais e nacionais estão envolvidas na seleção de candidaturas para o Legislativo nacional. Para isso, será elaborada uma avaliação dos estatutos partidários, assim como serão 
consideradas algumas pontuações advindas de observação participante realizada em convenções no estado de São Paulo. ${ }^{1}$ Por fim, interessa-nos verificar como as variações nos procedimentos de recrutamento influenciam o perfil dos candidatos e dos eleitos. Mais do que rebater argumentos, nossa contribuição está em apresentar novas evidências para o debate.

\section{O processo de seleção de candidatos}

Para avaliar os mecanismos de seleção de candidatos usados pelos partidos e suas conseqüências enfocaremos nesta seção as dimensões analíticas relacionadas com o tipo de candidato, de selecionadores $\mathrm{e}$ do método de escolha usado por cada partido investigado. Para isso serão examinadas as regras formais determinadas pela legislação eleitoral e partidária, bem como aquelas estabelecidas nos estatutos dos partidos. Em seguida, essas regras formais serão confrontadas com procedimentos informais observados nas convenções partidárias realizadas no primeiro semestre de 2006. Analisaremos, ainda, as listas partidárias que resultaram do processo de seleção dos partidos investigados realizados no período entre as eleições de 1994 e 2006.

\section{Quem pode ser candidato? ${ }^{2}$}

A primeira dimensão diz respeito a quem pode ser candidato a um cargo eletivo. A observação do cenário partidário brasileiro revela que quem quer ser candidato a deputado federal deve cumprir, de um lado, os requisitos da regra eleitoral nacional ${ }^{3} \mathrm{e}$, de outro, os que lhe impõe cada partido. A lei eleitoral estipula que todos os cidadãos têm o direito de eleger e, ao mesmo tempo, de serem eleitos para cargos de representação popular desde que cumpram com uma série de atributos: nacionalidade, idade (de 21 anos para deputado federal), não ter causas penais pendentes e filiação partidária na circunscrição por onde pretende concorrer. Esse último quesito é salientado no Art. 9: "Para concorrer às eleições, o candidato deverá possuir domicílio eleitoral na respectiva circunscrição pelo prazo de, pelo menos, um ano antes do pleito e estar com a filiação deferida pelo partido no mesmo prazo" (grifos nossos).
Dessa forma, a lei eleitoral obriga que todas as candidaturas sejam registradas via partidos políticos, o que coloca o Brasil entre os poucos países da América Latina que dá o monopólio da representação política às organizações partidárias. ${ }^{4}$ Em princípio, portanto, esse monopólio partidário, ao garantir o controle das lideranças sobre oportunidades de acesso a postos para aspirantes às carreiras políticas, permite a seus dirigentes a imposição de lealdades e de manter relações hierárquicas.

A legislação eleitoral (Lei 9504/97) também estipula no capítulo sobre as convenções para escolha de candidatos que as "normas para a escolha e substituição dos candidatos e para a formação de coligações serão estabelecidas no estatuto do partido, observadas as disposições desta Lei" (Art. 7). Já que são os partidos que formulam as regras de seleção de candidatos em seus estatutos, faz-se necessário verificar se neles existem mais restrições além daquelas ditadas pela lei.

Segundo os estatutos do PP, PFL/DEM, PMDB e PSDB, para que um filiado possa disputar uma candidatura a qualquer cargo público eletivo, ele terá que dar conta ao menos do critério estipulado pela legislação eleitoral, ou seja, a filiação partidária mínima de um ano. Somente no PT as restrições vão além do que exige a legislação:

Art. 128: São pré-requisitos para ser candidato do Partido:

a) estar filiado ao Partido, pelo menos, um ano antes do pleito;

b) estar em dia com a tesouraria do Partido;

c) assinar e registrar em Cartório o "Compromisso Partidário do Candidato Petista", de acordo com modelo aprovado pela instância nacional do Partido, até a realização da Convenção Oficial do Partido.

$\int 1^{\circ}$ : A assinatura do "Compromisso Partidário do Candidato Petista" indicará que o candidato está previamente de acordo com as normas e resoluções do Partido, tanto em relação à campanha quanto ao exercício do mandato. $\int 2^{\circ}$ : Quando houver comprovado descumprimento de qualquer uma das cláusulas do "Compromisso Partidário do Candidato Petista", assegurado o pleno direito de defesa à 
parte acusada, o candidato será passível de punição, que poderá ir da simples advertência até o desligamento do Partido com renúncia obrigatória ao mandato.

É importante salientar que o "Compromisso Partidário do Candidato Petista" é um documento criado pelo Diretório Nacional do PT, por meio do qual o partido estabelece normas, com abrangência nacional, para o comportamento do candidato durante a campanha e depois de eleito. Esse documento é um bom exemplo dos meios elaborados pelos dirigentes petistas para fortalecerem seu controle sobre as candidaturas e as respectivas campanhas eleitorais e, também, sobre os quadros eleitos. Entre outras regras, chamamos atenção para as seguintes condições: todo candidato deve contribuir financeiramente com o partido, é obrigado a veicular a sigla do partido em seu material de campanha e ainda restringe o financiamento de campanha. Caso eleito, o documento reforça o caráter partidário do mandato, seja por meio do dever de submeter ao partido os nomes que irão compor o primeiro e o segundo escalão do governo, seja por meio da formação de uma "bancada coletiva", no caso do Legislativo.

Como se pode observar, entre os partidos analisados o processo de seleção de candidatos do PT é o de maior exclusão, exigindo, além da filiação por um ano, contribuição financeira, compromisso programático e aprovação pela direção partidária ou apoio de parcela dos membros. Conforme veremos na sessão seguinte, tais restrições acabam redundando na composição de uma bancada de parlamentares mais orgânica partidariamente. Uma das explicações para esse padrão está na sua origem, extraparlamentar, portanto mais vinculado a variados setores sociais, bem como ao seu perfil ideológico e sua estratégia organizacional.

De acordo com estes dados, é possível classificar os principais partidos brasileiros em um ponto intermediário do intervalo maior inclusão/maior exclusão, tendendo mais para este pólo devido às exigências encontradas no PT. Embora o caso do PT em termos das regras que regem essa dimensão seja o mais exclusivo, nos demais partidos outras restrições também existem, mas não estão formalmente apresentadas em seus documentos. Como também veremos na próxima sessão, tais restrições estão mais relacionadas com o perfil socioeconômico e educacional dos cinco partidos investigados (Tabela 1).

\section{Quem escolhe os candidatos?}

A segunda dimensão a ser observada no processo de seleção partidária é a vinculada ao quadro de membros responsáveis pela escolha dos candidatos (os selecionadores). A identificação do corpo que detém esse controle revela os vários processos de tomada de decisões intrapartidários e indica os tipos de relações existentes entre os membros e os filiados do

Tabela 1

Requisitos para Ser Candidato Segundo a Lei Eleitoral e os Estatutos Partidários

\begin{tabular}{|c|c|c|}
\hline \multicolumn{2}{|c|}{} & \multicolumn{2}{c}{ maior exclusão } \\
\hline maior inclusão & $\begin{array}{c}\text { Membros partidários } \\
\text { (filiação) }\end{array}$ \\
\hline Todos os eleitores & PP & $\begin{array}{c}\text { Filiados com restrições } \\
\text { internas }\end{array}$ \\
\hline & PFL \\
& PMDB & PT \\
\hline
\end{tabular}

Fonte: Elaboração própria a partir do Código Eleitoral e Estatutos Partidários. 
partido. Assim, por exemplo, a seleção realizada a partir de eleições internas sinaliza um nível maior de inclusão dos filiados nesse processo decisório, ao passo que a escolha realizada por um único dirigente mostra uma estrutura decisória fechada e mais rígida.

O exame dessa relação é fundamental, pois viabiliza um raciocínio teórico sobre os vínculos existentes entre os dirigentes partidários tanto com seus filiados como com os futuros representantes. Diversos estudos têm avaliado esse aspecto por meio dos vários graus de inclusão da seleção. Dessa maneira, nos extremos temos, de um lado, o caso dos candidatos escolhidos pelo líder do partido, que detém o monopólio da seleção, e, de outro, a possibilidade de que a seleção seja definida nas eleições primárias dentro do partido, definindo, portanto, um nível máximo de participação. Estes são, evidentemente, os casos extremos que encontram pouca evidência no mundo real. Mesmo o caso dos partidos norte-americanos, que adotam as primárias, não constitui um claro exemplo de sistema seletivo altamente aberto. De fato, o processo de nomeação ocorre por meio das primárias, mas varia grandemente entre os estados, já que, em muitos casos, é a liderança partidária local que define a candidatura (Epstein, 1982).

No que diz respeito às relações com os parlamentares no caso em que a candidatura é definida por um único líder, supõe-se que haja maior disciplina interna, já que o aspirante depende mais dos dirigentes para conseguir uma candidatura. $\mathrm{O}$ contrário pode ser observado nos ambientes em que a nomeação depende mais dos votantes, embora o aparato partidário se mantenha controlando a estrutura de oportunidades.

Neste artigo, os métodos usados para selecionar os candidatos são classificados conforme o grau de inclusão. ${ }^{5}$ Em um extremo, situa-se o mecanismo com o mais alto nível de inclusão, em outro, é somente um líder que seleciona. Entre os dois extremos podemos identificar diversos mecanismos com variados níveis de participação. Assim, de acordo com o nível de inclusão verificado, temos um determinado tipo de controle do processo de escolha.

Para uma maior clareza de quem e de como são designados os candidatos, examinaremos também os procedimentos usados nessa seleção. Tais métodos podem ser por votação, envolvendo todos os filiados, somente os militantes, ou ambos, ou por indicação (nomeação). Segundo Rahat e Hazan (2001), estamos diante de um procedimento de votação quando o processo de seleção utiliza o voto para decidir quem será o candidato e qual sua posição na lista. Para isso, esse sistema requer que o candidato seja escolhido apenas pelo voto. Isto significa que não pode haver um acordo sobre uma lista. Ademais, os resultados devem ser legitimados via divulgação oficial. Ainda de acordo com esses autores, uma candidatura é definida por um sistema de nomeação quando são as lideranças partidárias que indicam os candidatos que comporão a lista partidária.

\section{Quem (e como) escolhe os candidatos a deputado federal}

O exame da dimensão acerca de quem realiza a escolha dos candidatos proporcionais e por quais sistemas de designação tem de ser feito considerando, particularmente, variáveis endógenas aos partidos. Isso porque a legislação eleitoral confere autonomia às organizações partidárias para definir suas regras internas no que tange a essa questão. Ademais, a lei estabelece mecanismos específicos para a escolha e/ou a homologação das candidaturas convenções -, assim como dita os prazos máximos de sua realização e registro dos candidatos nos órgãos oficiais da justiça eleitoral. ${ }^{6}$

Os estatutos do PFL, PP, PMDB e PSDB não diferem muito sobre quem escolhe os candidatos do partido. Neles é a convenção partidária estadual que homologa a chapa apresentada. A observação da dinâmica das convenções desses partidos para as eleições de 2006 revelou que há diferenças importantes entre eles no que diz respeito à participação dos filiados nesse processo de seleção. Com relação ao PP e ao PFL, a convenção funciona apenas como ato simbólico em que a lista partidária é homologada pelos presentes, sem que haja menção dos componentes e mesmo sem qualquer discussão sobre possíveis nomes a serem incluídos na lista previamente elaborada pelos dirigentes partidários. Trata-se, portanto, de um sistema de nomeação puro, ou seja, os candidatos integrantes das listas do PP e do PFL não passam por um processo de aprovação, configurando-se como processos mais exclusivos. 
Outro indicador que reforça o caráter restritivo desse processo nesses dois partidos é que não houve antes da realização da convenção eleições internas para a escolha dos convencionais ou mesmo para os cargos internos. As atuais direções permanecem nas atuais posições desde a formação do partido, com um ou outro quadro sendo remanejado, incluído ou mesmo substituído.

Em contrapartida, no PMDB e no PSDB, a participação dos filiados nas convenções e, portanto, na homologação da chapa partidária se dá de maneira mais ampla. Isso porque nesses dois partidos, embora a lista partidária também já chegue fechada na convenção, isto é, não há discussão sobre sua montagem entre os convencionais, estes participam do processo de homologação aprovando ou não a lista de candidatos previamente escolhida pela cúpula partidária. Em função disso, também estamos diante de um sistema de indicação, embora relativamente mais inclusivo, uma vez que é acompanhado por um processo de aprovação dos delegados. Isso, em última análise, acaba restringindo em algum grau a margem de manobra dos líderes organizativos, o que implica esforços contínuos por parte deles no sentido de manter e ampliar o número de adeptos sob sua influência. Normalmente outras questões relacionadas com as estratégias eleitorais são colocadas na cédula de votação para o convencional se posicionar. Pode, por exemplo, haver consulta sobre a realização ou não de coligações com determinados partidos tanto para os cargos majoritários como proporcionais.

Com relação aos dispositivos formais, a grande diferença aparece no documento do PT. Embora o resultado final do processo de seleção dos candidatos petistas somente seja conhecido na convenção estadual (no chamado Encontro), seu estatuto prevê o início dessa atividade de escolha no momento das indicações realizadas por diversas instâncias do partido. Isso fica explícito no artigo 129:

Art. 129: A Comissão Executiva da instância de direção correspondente somente examinará pedido de indicação à pré-candidatura se vier acompanhado de assinaturas ou votos favoráveis de no mínimo:

B - ao cargo de deputado federal:
B. a. $-1 / 3$ dos membros do Diretório Estadual; ou

B. b. $-5 \%$ das Comissões Executivas Municipais; ou

B. c. $-1 \%$ dos filiados no Estado; ou

B. d. - Encontro Setorial Estadual ou Nacional.

Assim, o PT, por meio de seu estatuto, se, de um lado, garante que amplos setores do partido participem desse processo indicando seus quadros, de outro, procura garantir que seus candidatos possuam alguma representatividade junto ao conjunto dos filiados, valorizando de alguma forma a democracia interna. Embora haja formalmente essa preocupação, ao longo das outras etapas um grupo mais restrito de lideranças mantém maior controle desse processo. Isso porque, conforme foi constatado em entrevistas com lideranças partidárias paulistanas, ${ }^{7}$ realizada a fase das indicações, os nomes são apresentados e registrados no Diretório Estadual. Após o registro dos nomes, a Secretaria de Organização do partido (SORG) inicia um processo de consulta pessoal às pré-candidaturas que foram indicadas pelo maior número de diretórios municipais. Feita a consulta, os nomes favoráveis à sua indicação são acatados pelos dirigentes do partido.

Mas, além disso, no caso de determinada candidatura não se mostrar viável ou eventualmente representar um setor da sociedade civil ou uma região do estado que possua outras lideranças mais influentes, inicia-se um período de "negociação" em torno de alguns nomes. Ademais, vale ressaltar que, caso a procura por legenda exceda o limite legal ou idealizado pelo partido, fica a cargo da Comissão Eleitoral efetuar os devidos cortes e propor uma chapa que será ratificada ou alterada mediante apreciação do Encontro Estadual. A formação dessa comissão eleitoral segue a proporcionalidade dos membros do Diretório Estadual, ou seja, os grupos internos que estão representados na Executiva estadual (23 membros) indicam os nomes para a composição dessa comissão, podendo coincidir ou não com os nomes que compõem a executiva estadual. A chapa proposta pela comissão eleitoral será votada pelos delegados no encontro estadual a partir de uma lista contendo os nomes que a comissão sugeriu e os nomes que estariam pleiteando a legen- 
da para concorrer às eleições. Nesse último caso haverá a abertura do plenário para defesa dessas novas candidaturas e votação de cada caso.

Assim, mesmo no caso do PT, em que há um processo de seleção mais inclusivo, na convenção predomina um sistema de nomeação aparentemente mais ampliado, pois o voto do delegado é para uma lista de candidatos (embora possa haver a inclusão de novos nomes durante o sistema de aprovação). No entanto, dificilmente isso ocorre em função da lista petista também ser nomeada, o que garante que sua composição seja controlada para dar conta quer dos grupos de poder interno quer de certa imagem do partido junto ao eleitorado.

Com base neste quadro, torna-se necessário examinar outra questão que diz respeito a quem pode participar das convenções e como se dá a escolha. No que tange ao processo de escolha dos convencionais, observam-se diferenças entre as instâncias partidárias. $\mathrm{Na}$ esfera local, os participantes são escolhidos por todos os filiados e, em outros casos, os membros são selecionados por delegados das instâncias inferiores. Para isso, o membro precisa ter de seis meses, no caso do PP, PMDB e PSDB, a um ano de filiação, no caso do PT.

Entre os componentes das convenções do PP, PFL, PMDB e PSDB estão os membros dos diretórios em cada nível e os vereadores, deputados estaduais e federais, senadores, presidentes e líderes da Câmara e do Senado, o presidente da República, governadores e prefeitos. É interessante observar a importância dos detentores de cargos eletivos sobre a escolha dos próximos candidatos nesses partidos. Os deputados podem participar em mais de uma instância, isto é, são membros efetivos das convenções nas esferas nacional, estadual ou municipal. No PP pode haver voto cumulativo, isto é, um membro pode votar na convenção estadual como delegado municipal, deputado federal e líder da Câmara tendo direito, portanto, a três votos.

Já no caso do P'T, os selecionadores dos candidatos são desde os filiados aos diretórios municipais, com suas indicações preliminares, passando pelos membros da Comissão eleitoral estadual, até os delegados eleitos para os "Encontros" (convenções petistas). Neste partido, participam também dos encontros: membros dos respectivos diretórios, membros dos diretórios estaduais e nacional, filiados no município e detentores de cargos eletivos em cada nível, sem direito a voto.

De acordo com os procedimentos formais acima discutidos, é possível classificar o PMDB e o PSDB na zona "seleção por órgão Executivo do partido"; já o PP e o PFL situam-se na zona "seleção por líder partidário” e o PT, como há envolvimento de diversos membros do partido com graus variados de influência nesse processo, está situado na zona "seleção por órgão colegiado". No entanto, no que se refere ao processo de escolha dos convencionais (selecionadores, em última instância, no PMDB, PSDB e PT), estes são designados por outros delegados, o que torna a atividade mais exclusiva e, mais uma vez, os grupos dirigentes com maior delegação têm grande influência no resultado final. Por sua vez, no PP e no PFL os líderes partidários, incluindo parlamenta-res mais orgânicos, detêm total controle sobre a seleção dos candidatos e, portanto, também sobre o acesso à lista partidária, caracterizando-se como os partidos mais fechados à participação popular. Apesar dessas diferenças quanto à dimensão dos selecionadores, com relação ao sistema de designação, todos os partidos examinados utilizam o mecanismo de indicação, embora tenham sido identificados graus variados de aprovação e, conseqüentemente, de participação dos militantes (convencionais) dos respectivos partidos examinados (Tabela 2).

\section{Resultado do processo de seleção: a composição das listas partidárias}

Analisadas as dimensões cruciais do processo de seleção desenvolvidas pelos atores partidários, cabe agora examinar o resultado dessas atividades: a composição das listas partidárias. Uma das variáveis de origem institucional arroladas por Mainwaring (2001, pp. 306-307) para explicar o fraco controle dos partidos brasileiros sobre as candidaturas é o número de candidatos lançados pelos partidos. De acordo com seu argumento, a legislação eleitoral incentiva os agentes partidários a lançarem um número muito elevado de candidatos para angariar mais votos e com isso aumentar sua representação 
Tabela 2

Quem (e Como) Escolhe os Candidatos à Câmara dos Deputados e o Grau de Inclusão

\begin{tabular}{|c|c|c|c|}
\hline \multicolumn{2}{|c|}{ maior inclusão/sistema de votação } & \multicolumn{3}{c|}{ menor exclusão/sistema de nomeção } \\
\hline \multirow{2}{*}{$\begin{array}{c}\text { Eleitorado } \\
\text { (internas abertas) }\end{array}$} & Filiados \\
\end{tabular}

Fonte: Elaboração própria a partir do Código Eleitoral e Estatutos Partidários.

na Câmara. Para checar as postulações de Mainwaring elaboramos a Tabela 3, que descreve os resultados dos processos de seleção ocorridos nas eleições entre 1994 e 2006 para a Câmara dos Deputados.

Como podemos verificar, embora a legislação eleitoral permita que cada partido componha sua lista partidária com um número de candidatos que corresponda a uma vez e meia a magnitude do distrito eleitoral onde vai concorrer, nenhuma das organizações partidárias analisadas chegou ao total de 694 candidaturas em nenhum dos pleitos. Nesse sentido, o PMDB foi o partido com o maior número de candidaturas no pleito de 1994 e 1998, apresentando 399 e 350 candidatos, respectivamente. Já nas eleições de 2002 e 2006 foi o PT que lançou as maiores listas partidárias, chegando, respectivamente, a 422 e 351 candidaturas. Por seu turno, o PFL teve as listas mais enxutas em $1994 \mathrm{e}$ 1998, lançando 236 e 276 candidatos, respectivamente, enquanto o PP foi o partido com o menor número de candidaturas tanto em 2002, quando apresentou uma lista com 194, como em 2006, com 175 candidatos.

Comparando-se a trajetória do número de candidatos nas chapas partidárias é interessante observar que enquanto PP, PT, PMDB e, em menor grau, o PFL/DEM indicaram tendência de diminuição desse montante, o PSDB foi o único partido que aumentou paulatinamente sua lista. Outra informação relevante, relacionada com essa tendência observada e com controle dos dirigentes partidários

Tabela 3

Número de Candidatos a Deputado Federal, Brasil (1994-2006)

\begin{tabular}{crrrr}
\hline & $\mathbf{1 9 9 4}$ & $\mathbf{1 9 9 8}$ & $\mathbf{2 0 0 2}$ & $\mathbf{2 0 0 6}$ \\
\hline PT & 373 & 328 & 422 & 351 \\
PMDB & 399 & 350 & 322 & 340 \\
PSDB & 272 & 292 & 275 & 308 \\
PFL/DEM & 236 & 276 & 230 & 227 \\
PPR/PPB/PP & 266 & 289 & 194 & 175 \\
Total de candidatos dos cinco partidos & 1.546 & 1.535 & 1.443 & 1.401 \\
Total geral de candidatos & 3.036 & 3.451 & 4.296 & 4.956 \\
Número de vagas permitido por listas partidárias* & 694 & 694 & 694 & 694 \\
\hline
\end{tabular}

*Número calculado segundo a legislação eleitoral que permite que cada partido lance uma vez e meia a magnitude do distrito, ou seja, o número de cadeiras que cada estado possui na Câmara dos Deputados.

Fonte: Dados coletados no TSE. 
com o acesso à lista partidária, é a de que ao longo desses pleitos se reduziu consistentemente o percentual de candidaturas dos cinco principais partidos em comparação com o total geral de candidaturas apresentado por todos os partidos, o qual seguiu aumentando gradativamente nesse período. Enquanto o percentual de candidaturas desses partidos foi de 51\% em 1994 para 44, 5\% em 1998, chegou a $33,6 \%$ em 2002 e, em 2006, caiu para 28,3\%. Por que os maiores partidos lançaram menos candidatos se a legislação eleitoral foi mantida? Uma das respostas possíveis tem a ver com as estratégias eleitorais de seus dirigentes partidários que, ao passarem a ter maior domínio do ambiente eleitoral, começaram a repensar seus cálculos políticos para se manterem em vantagem no jogo político. Ao mesmo tempo, esses dados também revelam que outros partidos no sistema partidário também passaram a contribuir decisivamente para o aumento do número de ofertas de candidatos no mercado eleitoral.

Vimos que os partidos examinados controlam o processo de seleção por diversos meios. Entre os mecanismos identificados estão o método de formação da lista, isto é, por indicação e não por votação, e o número de candidatos que vai figurar na lista final. Além desse sistema, vimos que a forma de convocação para as convenções, a possibilidade de intervenção dos diretórios de instância superior sobre as inferiores e a criação de comissões provisórias e interventoras (no caso do PMDB) são outros mecanismos utilizados pelos dirigentes partidários para garantir seu controle sobre os resultados desse processo de seleção. Assim, observa-se que, diferentemente do que defende Mainwaring (1999), o sistema eleitoral e a lista aberta não têm promovido conseqüências tão negativas à imagem dos partidos. Embora tenham sido identificados graus distintos de estruturação partidária, os partidos demonstram manter controle sobre o processo de seleção de candidatos e ao acesso à lista partidária. Dessa maneira, os dirigentes vêm agindo estrategicamente para diminuir a incerteza eleitoral e garantir a sobrevivência do partido no sistema político. Além da preocupação com o ambiente externo, em partidos (como, por exemplo, o PSDB e o PT) em que a disputa interna é muito acirrada, a centralização do processo de seleção é resultado da ação das lide- ranças no sentido de preservar a linha de autoridade intrapartidária, o que implica no controle de outros recursos vitais para a estabilidade organizativa.

Perfil dos candidatos e dos eleitos à Câmara dos Deputados

Para concluir a discussão sobre o recrutamento partidário e a seleção de candidaturas, será apresentado o perfil socioeconômico dos candidatos e dos eleitos pelas as legendas partidárias. Especificamente, interessa-nos verificar se as diferenças encontradas no processo de recrutamento dos cinco partidos repercutem no perfil dos candidatos e dos eleitos. Serão analisados os dados tornados públicos pelo Tribunal Superior Eleitoral e organizados pelo NUSP/UFPR, que se referem a sexo, idade, escolaridade, profissão e patrimônio declarado.

Sexo

Apesar do sistema de cotas adotado no Brasil, que reserva às mulheres $20 \%$ do número de candidaturas nos partidos, elas representaram apenas $12 \%$ dos recrutados. Porcentagem - já baixa - que elas não conseguem sustentar entre o número de candidatos eleitos. Apenas 7,8\% dos eleitos para a Câmara dos Deputados em 2006 foram mulheres (ver Tabela 1). Houve pouca variação entre as legendas no que se refere ao número de candidaturas femininas.

Se adotarmos o pressuposto de que um processo de seleção de candidaturas mais inclusivo pode refletir em mais espaço para as diversidades sociais, ao analisarmos os procedimentos dos quatro grandes partidos, seria de se esperar que o número de candidatas e eleitas nas legendas obedecesse à seguinte ordem ( $\mathrm{PP}<\mathrm{PFL}<\mathrm{PMDB}<\mathrm{PSDB}<\mathrm{PT}$ ). Os dados não contrariaram tal expectativa, nota-se apenas uma inversão entre a posição do PT e a do PSDB. No que se refere à porcentagem de candidatas, a seqüência em ordem crescente ficou: PP $(8,0 \%)<\operatorname{PMDB}(11,5 \%)<\operatorname{PFL}(11,9 \%)<$ PT $(12 \%)$ $<\operatorname{PSDB}(14,9 \%)$. Já em relação à porcentagem de eleitas, tem-se: PSDB $(4,5 \%)<\mathrm{PP}(7,3 \%)<$ PFL $(7,7 \%)<$ PT $(8,4 \%)<$ PMDB $(10,1 \%)$. O resultado mais desviante foi aquele referente ao número de eleitas pelo PSDB. Curiosamente, o partido que mais recrutou mulheres foi o que menos as elegeu. 
Os números encontrados remetem à discussão proposta por Norris e Lovenduski (1995). Os autores questionam se o baixo número de mulheres candidatas e eleitas pode ser resultado da ausência de demanda dos selecionadores - que tenderiam, direta ou indiretamente, a dificultar as candidaturas femininas - ou da falta de oferta de candidatas - na medida em que a divisão do trabalho dentro de casa, a discriminação no mercado de trabalho e o tradicional padrão de socialização fariam com que a mulher tivesse menos recursos de tempo e dinheiro, além de menor nível de ambição política.

Podemos problematizar ainda mais, ao questionarmos se o intervalo entre o número de candidatas e o de eleitas se justifica por demandas dos elei- tores - que ainda que tenham a opção de votar em mulheres, preferem o voto nos homens -, por discriminação na distribuição de recursos partidários, ou por ambos os fatores.

\section{Idade}

Foi possível constatar que a faixa etária que comporta o maior número de candidatos e eleitos nos cinco partidos é entre 46 e 55 anos, o que se alinha com uma tendência presente em vários países e já apontada pela literatura internacional.

O PMDB, o PP e o PFL têm candidatos mais idosos do que o PSDB e o PT. Possivelmente, trata-se de uma decorrência da trajetória das legen-

Tabela 4

Distribuição de Candidatos e Eleitos à Câmara dos Deputados por Partidos Políticos e Sexo

\begin{tabular}{|c|c|c|c|c|c|c|c|c|c|c|c|c|}
\hline & \multicolumn{2}{|c|}{ PFL $(\%)$} & \multicolumn{2}{|c|}{$\mathrm{PP}(\%)$} & \multicolumn{2}{|c|}{$\operatorname{PSDB}(\%)$} & \multicolumn{2}{|c|}{ PMDB (\%) } & \multicolumn{2}{|c|}{ PT (\%) } & \multicolumn{2}{|c|}{ Total (\%) } \\
\hline & $\begin{array}{l}\text { Candi- } \\
\text { datos }\end{array}$ & $\begin{array}{l}\text { Elei- } \\
\text { tos }\end{array}$ & $\begin{array}{l}\text { Candi- } \\
\text { datos }\end{array}$ & $\begin{array}{l}\text { Elei- } \\
\text { tos }\end{array}$ & $\begin{array}{c}\text { Candi- } \\
\text { datos }\end{array}$ & $\begin{array}{c}\text { Elei- } \\
\text { tos }\end{array}$ & $\begin{array}{l}\text { Candi- } \\
\text { datos }\end{array}$ & $\begin{array}{l}\text { Elei- } \\
\text { tos }\end{array}$ & $\begin{array}{l}\text { Candi- } \\
\text { datos }\end{array}$ & $\begin{array}{c}\text { Elei- } \\
\text { tos }\end{array}$ & $\begin{array}{l}\text { Candi- } \\
\text { datos }\end{array}$ & $\begin{array}{l}\text { Elei- } \\
\text { tos }\end{array}$ \\
\hline Feminino & 11,9 & 7,7 & 8,0 & 7,3 & 14,9 & 4,5 & 11,5 & 10,1 & 12,0 & 8,4 & 12,0 & 7,8 \\
\hline Masculino & 88,1 & 92,3 & 92,0 & 92,7 & 85,1 & 95,5 & 88,5 & 89,9 & 88,0 & 91,6 & 88,0 & 92,2 \\
\hline Total & 100,0 & 100,0 & 100,0 & 100,0 & 100,0 & 100,0 & 100,0 & 100,0 & 100,0 & 100,0 & 100,0 & 100,0 \\
\hline
\end{tabular}

Fonte: Banco de dados “Eleições 2006: candidatos ao Poder Legislativo no Brasil” do Núcleo de Pesquisa em Sociologia Política Brasileira - UFPR.

Tabela 5

Distribuição de Candidatos e Eleitos à Câmara dos Deputados por Partidos Políticos e Faixa Etária

\begin{tabular}{|c|c|c|c|c|c|c|c|c|c|c|c|c|}
\hline \multirow[b]{2}{*}{ Faixa etária } & \multicolumn{2}{|c|}{ PFL (\%) } & \multicolumn{2}{|c|}{$\mathrm{PP}(\%)$} & \multicolumn{2}{|c|}{ PSDB $(\%)$} & \multicolumn{2}{|c|}{ PMDB (\%) } & \multicolumn{2}{|c|}{ PT $(\%)$} & \multicolumn{2}{|c|}{ Total (\%) } \\
\hline & $\begin{array}{c}\text { Candi- } \\
\text { datos }\end{array}$ & $\begin{array}{l}\text { Elei- } \\
\text { tos }\end{array}$ & $\begin{array}{c}\text { Candi- } \\
\text { datos }\end{array}$ & $\begin{array}{l}\text { Elei- } \\
\text { tos }\end{array}$ & $\begin{array}{c}\text { Candi- } \\
\text { datos }\end{array}$ & $\begin{array}{l}\text { Elei- } \\
\text { tos }\end{array}$ & $\begin{array}{c}\text { Candi- } \\
\text { datos }\end{array}$ & $\begin{array}{l}\text { Elei- } \\
\text { tos }\end{array}$ & $\begin{array}{c}\text { Candi- } \\
\text { datos }\end{array}$ & $\begin{array}{c}\text { Elei- } \\
\text { tos }\end{array}$ & $\begin{array}{c}\text { Candi- } \\
\text { datos }\end{array}$ & $\begin{array}{l}\text { Elei- } \\
\text { tos }\end{array}$ \\
\hline De 16 a 25 anos & 1,3 & 0,0 & 0,6 & 0,0 & 1,3 & 0,0 & 0,3 & 0,0 & 0,3 & 0,0 & 0,7 & 0,0 \\
\hline De 26 a 35 anos & 8,8 & 10,8 & 10,8 & 12,2 & 9,1 & 6,1 & 7,9 & 4,5 & 9,1 & 4,8 & 9,0 & 7,0 \\
\hline De 36 a 45 anos & 24,2 & 21,5 & 22,7 & 9,8 & 27,5 & 25,7 & 22,6 & 13,5 & 34,3 & 22,9 & 26,9 & 19,2 \\
\hline De 46 a 55 anos & 35,7 & 32,3 & 34,1 & 36,6 & 34,0 & 31,8 & 32,9 & 33,7 & 39,7 & 53,0 & 35,4 & 38,1 \\
\hline De 56 a 65 anos & 18,1 & 21,5 & 22,2 & 31,7 & 21,0 & 22,7 & 22,4 & 31,5 & 16,0 & 19,3 & 19,8 & 25,0 \\
\hline De 66 a 75 anos & 10,6 & 12,3 & 8,0 & 7,3 & 6,1 & 9,1 & 10,9 & 11,2 & 0,3 & 0,0 & 6,8 & 7,8 \\
\hline De 76 a 85 anos & 1,3 & 1,5 & 1,7 & 2,4 & 1,0 & 4,5 & 2,6 & 4,5 & 0,0 & 0,0 & 1,3 & 2,6 \\
\hline Acima de 86 anos & 0,0 & 0,0 & 0,0 & 0,0 & 0,0 & 0,0 & 0,3 & 1,1 & 0,3 & 0,0 & 0,1 & 0,3 \\
\hline Total & 100,0 & 100,0 & 100,0 & 100,0 & 100,0 & 100,0 & 100,0 & 100,0 & 100,0 & 100,0 & 100,0 & 100,0 \\
\hline
\end{tabular}

Fonte: Banco de dados "Eleições 2006: candidatos ao Poder Legislativo no Brasil” do Núcleo de Pesquisa em Sociologia Política Brasileira-UFPR. 
das e de seus líderes, que vêm desde o tempo do MDB e da Arena, do período ditatorial entre 1964 e 1982. O MDB deu origem ao PMDB e a Arena, ao PDS e ao PFL, que hoje são PP e DEM, respectivamente. Já o PT é um partido novo, com pouco mais de vinte anos de história, nascido do movimento social e não de uma subdivisão de legenda. ainda que tenha herdado alguns políticos do MDB. Em síntese, usando as expressões de Norris e Lovenduski (1995), acredita-se que a variação de idade entre os partidos possa ser mais bem explicada pela oferta de candidatos do que pela demanda dos selecionadores.

\section{Educação}

$\mathrm{Na}$ disputa para a Câmara dos Deputados de 2006, houve uma franca preferência dos partidos e dos eleitores por candidatos com curso superior. Para Ranney (1965) e Norris e Lovenduski (1995), a tendência para a grande presença de pessoas com alta escolaridade em disputas eleitorais pode ser explicada como uma questão de demanda dos selecionadores: os membros dos partidos preferem aqueles porque escolaridade denota habilidade, capacidade e prestígio social. Mas Norris e Lovenduski (1995) consideram também a questão como sendo de oferta. Os autores lembram que estudos sobre participação política mostram que a educação é um dos principais requisitos para o ativismo, pois proporciona conhecimento e interesse político.

Nas eleições para a Câmara em 2006, constatamos que os dois partidos que ampliaram o espaço para a seleção de candidaturas e que mais elegeram pessoas de baixa escolaridade foram PP e PT, ao contrário do PSDB, menos aberto para o lançamento de candidaturas de políticos com baixa escolaridade.

Desta forma, de acordo com as expectativas criadas com a análise do processo de recrutamento, o PT correspondeu ao esperado, na medida em que se mostrou mais aberto para as diversidades da população. Já o PP comportou-se da maneira oposta da esperada. Uma vez que o partido conta com um processo de recrutamento e seleção de candidaturas muito centralizado, a expectativa era de que ele não estivesse aberto às diversidades, mas não foi o que aconteceu. Cabe salientar que o PP, em São Paulo, sempre esteve muito associado ao malufismo, de caráter essencialmente populista, marcado pelo assistencialismo. A presença em São Paulo - estado em que o PP é tido como uma legenda forte - de uma base de sustentação para o populismo partidário junto às comunidades ajuda a explicar a presença de candidatos com pouca escolaridade. Deve-se ressaltar, no entanto, que a base de sustentação do partido em

Tabela 6

Distribuição de Candidatos e Eleitos à Câmara dos Deputados por Partidos Políticos e Escolaridade

\begin{tabular}{|c|c|c|c|c|c|c|c|c|c|c|c|c|}
\hline \multirow[b]{2}{*}{ Escolaridade } & \multicolumn{2}{|c|}{ PFL $(\%)$} & \multicolumn{2}{|c|}{$\mathrm{PP}(\%)$} & \multicolumn{2}{|c|}{$\operatorname{PSDB}(\%)$} & \multicolumn{2}{|c|}{ PMDB (\%) } & \multicolumn{2}{|c|}{ PT $(\%)$} & \multicolumn{2}{|c|}{ Total $(\%)$} \\
\hline & $\begin{array}{l}\text { Candi- } \\
\text { datos }\end{array}$ & $\begin{array}{c}\text { Elei- } \\
\text { tos }\end{array}$ & $\begin{array}{l}\text { Candi- } \\
\text { datos }\end{array}$ & $\begin{array}{c}\text { Elei- } \\
\text { tos }\end{array}$ & $\begin{array}{l}\text { Candi- } \\
\text { datos }\end{array}$ & $\begin{array}{l}\text { Elei- } \\
\text { tos }\end{array}$ & $\begin{array}{c}\text { Candi- } \\
\text { datos }\end{array}$ & $\begin{array}{l}\text { Elei- } \\
\text { tos }\end{array}$ & $\begin{array}{l}\text { Candi- } \\
\text { datos }\end{array}$ & $\begin{array}{l}\text { Elei- } \\
\text { tos }\end{array}$ & $\begin{array}{l}\text { Candi- } \\
\text { datos }\end{array}$ & $\begin{array}{c}\text { Elei- } \\
\text { tos }\end{array}$ \\
\hline Lê e escreve & 0,0 & 0,0 & 0,0 & 0,0 & 0,0 & 0,0 & 0,0 & 0,0 & 0,3 & 1,2 & 0,1 & 0,3 \\
\hline Fundamental incompleto & 1,3 & 0,0 & 1,1 & 0,0 & 1,0 & 1,5 & 0,9 & 0,0 & 2,6 & 1,2 & 1,4 & 0,6 \\
\hline Fundamental completo & 2,6 & 0,0 & 5,7 & 4,9 & 3,6 & 1,5 & 5,6 & 1,1 & 4,9 & 2,4 & 4,5 & 1,7 \\
\hline Médio incompleto & 1,8 & 0,0 & 3,4 & 2,4 & 1,9 & 0,0 & 2,9 & 1,1 & 1,7 & 0,0 & 2,3 & 0,6 \\
\hline Médio completo & 15,4 & 12,3 & 19,9 & 9,8 & 12,3 & 0,0 & 15,3 & 9,0 & 14,9 & 10,8 & 15,1 & 8,4 \\
\hline Superior incompleto & 11,0 & 7,7 & 9,7 & 2,4 & 9,7 & 7,6 & 12,1 & 6,7 & 11,4 & 8,4 & 10,9 & 7,0 \\
\hline Superior completo & 67,8 & 80,0 & 60,2 & 80,5 & 71,5 & 89,4 & 63,2 & 82,0 & 64,3 & 75,9 & 65,7 & 81,4 \\
\hline Total & 100,0 & 100,0 & 100,0 & 100,0 & 100,0 & 100,0 & 100,0 & 100,0 & 100,0 & 100,0 & 100,0 & 100,0 \\
\hline
\end{tabular}

Fonte: Banco de dados “Eleições 2006: candidatos ao Poder Legislativo no Brasil” do Núcleo de Pesquisa em Sociologia Política Brasileira - UFPR. 
outros estados não necessariamente reproduz o caráter populista, assistencialista de São Paulo.

\section{Ocupação}

De modo geral, os perfis dos candidatos e dos eleitos apresentam algumas distinções, mas não variam muito de partido para partido no que se refere à ocupação. Em todos os partidos, destacam-se os desempenhos positivos dos políticos e dos profissionais liberais. Por outro lado, os trabalhadores manuais aparecem pouco na lista de candidatos e eleitos.

O primeiro ponto a ser abordado nesta análise refere-se à proeminência dos políticos em relação aos demais profissionais no momento da seleção das candidaturas e do processo eleitoral. É constante em todos os partidos a alta taxa de políticos que se recandidatam e conseguem se reeleger. Eles correspondem a aproximadamente $20 \%$ das candidaturas e a de $40 \%$ a $50 \%$ dos eleitos.

A esse respeito, deve-se considerar que tal tendência está presente em outros países também, como aponta a literatura internacional. Gallanher e Marsh (1988) ao analisarem o recrutamento partidário interessaram-se não apenas pelos aspectos formais do processo, mas também pelos informais, observando as qualidades dos aspirantes que os selecionadores consideravam importantes e positivas. Com a análise de nove países europeus, concluíram que aqueles que já são deputados e buscam a reeleição possuem a maior chance de terem suas candidaturas aceitas e serem eleitos, configurando então o melhor perfil de aspirante.

De acordo com esses autores, os incumbentes saem na frente na disputa porque já contam com uma base organizacional dentro do partido e, em geral, são pessoas com certo grau de apelo eleitoral. Nesse caso, apelo eleitoral deve ser entendido como uma característica subjetiva referente à maneira articulada de falar, à presença de espírito, à aparência e à habilidade para lidar com o povo.

Ademais, no caso especificamente brasileiro, foi preciso considerar, ao analisarmos o desempenho dos incumbentes, o uso do dispositivo da candidatura nata, vigente até as eleições municipais de 2000.

Como já foi mencionado, é verificável ainda grande presença de profissionais liberais, particu- larmente da área de direito, jornalismo e magistério entre os candidatos e os eleitos. Neste caso, também é possível identificar uma tendência que perpassa vários países, de acordo com a literatura internacional. Norris e Lovenduski (1995) chamam a atenção para a tendência de pessoas vinculadas ao que define como talking professions de se apresentarem para uma candidatura. Trata-se também de uma questão de oferta de aspirantes e não apenas de demanda dos selecionadores.

Ainda sobre isso, é preciso pontuar o que Ranney (1965) definiu como brokerage occupations, profissões de classe média que proporcionam algumas vantagens para a construção de uma carreira política como, por exemplo, flexibilidade de hora de trabalho e de férias, independência profissional, segurança financeira, network pública, status social, experiência e conhecimento da política. Ranney pontua que devido a todas essas vantagens haveria uma maior oferta de aspirantes oriunda desse segmento.

A reduzida taxa de trabalhadores manuais é também constante em todas as legendas. Tal tendência perpassa diferentes países e épocas. Em 1965, Ranney observou que, embora houvesse 64\% de trabalhadores manuais na população inglesa, a classe contava com apenas 3\% das candidaturas do Partido Conservador. Já a categoria de proprietários e executivos tendia a ser sobre-representada: $13 \%$ na população e $39 \%$ entre os candidatos conservadores selecionados.

No Partido Trabalhista, Ranney esperava encontrar mais espaço para os trabalhadores manuais, na medida em que a legenda era considerada uma arma política capaz de levantar e representar o movimento trabalhista. Além disso, muitos dos votos dos trabalhistas vinham de filiados sindicalizados, que deveriam ser recompensados com candidaturas pelo trabalho que desempenhavam no movimento. Contudo, predominou o número de candidaturas de advogados, jornalistas e professores.

No Brasil, Leôncio Rodrigues (2006) com base nos estudos que realizou sobre as $51^{\circ}$ e $52^{\circ}$ legislaturas aponta para a existência de perfis partidários diferenciados no que se refere à ocupação, que tendem a se relacionar com suas localizações no eixo direita-centro-esquerda. Para o autor, a classificação so- 
Tabela 7

Distribuição de Candidatos e Eleitos à Câmara dos Deputados por Partidos Políticos e Ocupação

\begin{tabular}{|c|c|c|c|c|c|c|c|c|c|c|c|c|}
\hline \multirow[b]{2}{*}{ Profissões } & \multicolumn{2}{|c|}{ PFL $(\%)$} & \multicolumn{2}{|c|}{$\mathrm{PP}(\%)$} & \multicolumn{2}{|c|}{$\operatorname{PSDB}(\%)$} & \multicolumn{2}{|c|}{ PMDB (\%) } & \multicolumn{2}{|c|}{ PT $(\%)$} & \multicolumn{2}{|c|}{ Total $(\%)$} \\
\hline & $\begin{array}{c}\text { Candi- } \\
\text { datos }\end{array}$ & $\begin{array}{c}\text { Elei- } \\
\text { tos }\end{array}$ & $\begin{array}{c}\text { Candi- } \\
\text { datos }\end{array}$ & $\begin{array}{l}\text { Elei- } \\
\text { tos }\end{array}$ & $\begin{array}{c}\text { Candi- } \\
\text { datos }\end{array}$ & $\begin{array}{l}\text { Elei- } \\
\text { tos }\end{array}$ & $\begin{array}{l}\text { Candi- } \\
\text { datos }\end{array}$ & $\begin{array}{c}\text { Elei- } \\
\text { tos }\end{array}$ & $\begin{array}{l}\text { Candi- } \\
\text { datos }\end{array}$ & $\begin{array}{c}\text { Elei- } \\
\text { tos }\end{array}$ & $\begin{array}{l}\text { Candi- } \\
\text { datos }\end{array}$ & $\begin{array}{c}\text { Elei- } \\
\text { tos }\end{array}$ \\
\hline Advogado & 13,2 & 9,2 & 10,2 & 8,4 & 12,3 & 13,6 & 10,6 & 5,6 & 10,9 & 8,4 & 11,4 & 8,1 \\
\hline $\begin{array}{l}\text { Aposentado (exceto servidor } \\
\text { público) }\end{array}$ & 0,9 & 0,0 & 3,4 & 0,0 & 1,0 & 1,5 & 1,5 & 0,0 & 1,1 & 0,0 & 1,4 & 0,3 \\
\hline Bancário e Economiário & 0,0 & 0,0 & 0,6 & 3,6 & 0,0 & 0,0 & 0,3 & 0,0 & 3,7 & 3,6 & 1,1 & 0,9 \\
\hline Comerciante & 1,8 & 3,1 & 3,4 & 0,0 & 2,6 & 1,5 & 4,1 & 1,1 & 1,1 & 0,0 & 2,6 & 1,2 \\
\hline Dona de casa & 0,0 & 0,0 & 0,0 & 0,0 & 0,0 & 0,0 & 0,3 & 0,0 & 0,3 & 0,0 & 0,1 & 0,0 \\
\hline Empresário & 7,0 & 7,7 & 11,9 & 1,2 & 8,7 & 3,0 & 11,5 & 10,1 & 1,7 & 1,2 & 7,8 & 6,1 \\
\hline Engenheiro & 4,8 & 6,2 & 6,3 & 1,2 & 3,2 & 6,1 & 3,2 & 6,7 & 2,0 & 1,2 & 3,6 & 6,1 \\
\hline Estudante, Bolsista, Estagiário & 1,8 & 0,0 & 1,1 & 0,0 & 1,6 & 0,0 & 0,3 & 0,0 & 0,6 & 0,0 & 1,0 & 0,0 \\
\hline Industrial & 0,0 & 0,0 & 0,6 & 0,0 & 0,3 & 0,0 & 0,0 & 0,0 & 0,0 & 0,0 & 0,1 & 0,3 \\
\hline Médico & 4,8 & 7,7 & 5,7 & 9,6 & 5,5 & 6,1 & 3,5 & 4,5 & 4,3 & 9,6 & 4,6 & 6,4 \\
\hline Professor, ensino superior & 1,3 & 3,1 & 1,1 & 4,8 & 3,6 & 0,0 & 0,9 & 0,0 & 4,6 & 4,8 & 2,5 & 2,6 \\
\hline $\begin{array}{l}\text { Sacerdote ou Membro de Or- } \\
\text { dem ou seita religiosa }\end{array}$ & 0,4 & 0,0 & 1,1 & 0,0 & 0,3 & 0,0 & 1,5 & 1,1 & 0,0 & 0,0 & 0,6 & 0,3 \\
\hline $\begin{array}{l}\text { Servidor público civil aposen- } \\
\text { tado }\end{array}$ & 1,3 & 0,0 & 1,7 & 1,2 & 1,3 & 0,0 & 1,5 & 0,0 & 1,4 & 1,2 & 1,4 & 0,3 \\
\hline Artes/Desportos & 0,9 & 0,0 & 0,0 & 1,2 & 0,6 & 0,0 & 0,0 & 0,0 & 1,7 & 1,2 & 0,7 & 0,3 \\
\hline $\begin{array}{l}\text { Atividades de prestação de ser- } \\
\text { viços }\end{array}$ & 1,3 & 0,0 & 0,6 & 0,0 & 0,6 & 0,0 & 1,5 & 1,1 & 1,1 & 0,0 & 1,1 & 0,3 \\
\hline Economia/Administração & 3,5 & 3,1 & 2,8 & 3,6 & 4,9 & 3,0 & 3,2 & 4,5 & 2,6 & 3,6 & 3,4 & 3,2 \\
\hline Funcionários públicos & 3,1 & 0,0 & 4,5 & 0,0 & 6,1 & 3,0 & 5,6 & 2,2 & 8,0 & 0,0 & 5,8 & 1,7 \\
\hline $\begin{array}{l}\text { Outras profissões com forma- } \\
\text { cão superior }\end{array}$ & 2,6 & 3,1 & 1,1 & 2,4 & 3,9 & 3,0 & 3,5 & 2,2 & 2,9 & 2,4 & 3,0 & 2,3 \\
\hline Polícia civil e Polícia militar & 3,5 & 0,0 & 1,1 & 0,0 & 0,3 & 0,0 & 0,6 & 0,0 & 0,9 & 0,0 & 1,1 & 0,0 \\
\hline Político & 23,3 & 43,1 & 19,3 & 43,4 & 16,5 & $50,0-$ & 23,5 & 51,7 & 22,9 & 43,4 & 21,3 & 47,7 \\
\hline Produtor agropecuário & 1,3 & 1,5 & 2,8 & 1,2 & 1,0 & 0,0 & 1,5 & 1,1 & 0,9 & 1,2 & 1,4 & 1,5 \\
\hline $\begin{array}{l}\text { Trabalhadores assalariados da } \\
\text { saúde }\end{array}$ & 0,0 & 0,0 & 0,0 & 0,0 & 0,3 & 1,5 & 0,3 & 0,0 & 0,0 & 0,0 & 0,1 & 0,3 \\
\hline $\begin{array}{l}\text { Trabalhadores assalariados ur- } \\
\text { banos }\end{array}$ & 4,8 & 1,5 & 4,0 & 4,8 & 6,5 & 0,0 & 4,7 & 2,2 & 5,4 & 4,8 & 5,2 & 2,0 \\
\hline $\begin{array}{l}\text { Trabalhadores da área de comu- } \\
\text { nicação }\end{array}$ & 3,5 & 4,6 & 2,8 & 1,2 & 2,3 & 0,0 & 2,1 & 1,1 & 0,6 & 1,2 & 2,1 & 1,7 \\
\hline Trabalhadores da educação & 0,9 & 0,0 & 1,7 & 6,0 & 2,6 & 0,0 & 3,2 & 1,1 & 8,9 & 6,0 & 3,9 & 1,7 \\
\hline Trabalhadores do setor rural & 0,9 & 1,5 & 2,3 & 1,2 & 0,6 & 0,0 & 1,5 & 0,0 & 0,9 & 1,2 & 1,1 & 0,6 \\
\hline Militar reformado & 1,3 & 0,0 & 0,6 & 0,0 & 0,6 & 0,0 & 0,0 & 0,0 & 0,0 & 0,0 & 0,4 & 0,3 \\
\hline Outros & 11,5 & 4,6 & 9,1 & 4,8 & 12,6 & 4,5 & 9,7 & 3,4 & 11,7 & 4,8 & 11,0 & 3,8 \\
\hline Total & 100,0 & 100,0 & 100,0 & 100,0 & 100,0 & 100,0 & 100,0 & 100,0 & 100,0 & 100,0 & 100,0 & 100,0 \\
\hline
\end{tabular}

Fonte: Banco de dados “Eleições 2006: candidatos ao Poder Legislativo no Brasil” do Núcleo de Pesquisa em Sociologia Política Brasileira - UFPR. 
ciológica dos deputados, efetuada com base na atividade ocupacional, é um indicador razoável do status dos meios sociais de origem dos parlamentares antes da ascensão econômica advinda com a entrada na vida pública.

Rodrigues parte do principio que pessoas de famílias ricas muito dificilmente procuram os partidos de esquerda para iniciarem a sua vida política. Da mesma maneira, acredita que os candidatos de classe mais baixa não devem procurar os partidos de direita, pois percebem que nesses predominam políticos mais ricos. Ou seja, segundo o autor, existem obstáculos pequenos e implícitos de caráter econômico, educacional, relativo à idade, à natureza étnica, ao status etc.

Em outro estudo (2002), Rodrigues analisou a composição da $51^{\circ}$ Legislatura, constatando que o número de empresários é maior nos partidos de direita do que nos de centro e de esquerda. Naquele momento, o PFL e o PPB eram as legendas que apresentavam maior taxa de empresários, seguidos pelo PMDB. Os resultados a respeito da disputa de 2006 reforçam os achados de Rodrigues sobre aquela legislatura, com exceção para o PP que, embora tenha selecionado $11,9 \%$ de empresários, elegeu apenas 1,2\% com essa ocupação. Mas o PFL e o
PMDB permaneceram sendo os partidos com mais candidatos e eleitos empresários.

Em relação aos profissionais liberais, os achados de Rodrigues se diferenciam dos apresentados na eleição de 2006. Havia na $51^{\circ}$ legislatura uma tendência de crescimento do número de profissionais liberais quando se deslocava dos partidos de direita para os de esquerda. Tal variação não ocorreu em 2006, pois nota-se um maior número de profissionais liberais entre os candidatos e os eleitos do centro e de direita do que nos partidos de esquerda.

O PP e o PT foram os partidos que mais elegeram trabalhadores manuais. A inserção dos trabalhadores no PT corresponde ao que era de se esperar de um partido de esquerda e de massa. Corresponde ainda ao padrão de recrutamento de candidaturas, mais aberto. No entanto, do PP não se esperava tal inserção da massa trabalhadora, uma vez que se trata de um partido de direita e com o processo de recrutamento muito fechado. Novamente aqui, a explicação disso pode estar em seu caráter populista.

\section{Patrimônio}

Fernando Rodrigues (2006) faz um vasto levantamento sobre o patrimônio pessoal dos candi-

Tabela 8

Distribuição de Candidatos e Eleitos à Câmara dos Deputados por Partidos Políticos e Patrimônio

\begin{tabular}{|c|c|c|c|c|c|c|c|c|c|c|c|c|}
\hline \multirow[b]{2}{*}{ Patrimônio } & \multicolumn{2}{|c|}{ PFL (\%) } & \multicolumn{2}{|c|}{ PP (\%) } & \multicolumn{2}{|c|}{ PSDB (\%) } & \multicolumn{2}{|c|}{ PMDB (\%) } & \multicolumn{2}{|c|}{ PT (\%) } & \multicolumn{2}{|c|}{ Total (\%) } \\
\hline & $\begin{array}{l}\text { Candi- } \\
\text { datos }\end{array}$ & $\begin{array}{l}\text { Elei- } \\
\text { tos }\end{array}$ & $\begin{array}{l}\text { Candi- } \\
\text { datos }\end{array}$ & $\begin{array}{l}\text { Elei- } \\
\text { tos }\end{array}$ & $\begin{array}{c}\text { Candi- } \\
\text { datos }\end{array}$ & $\begin{array}{l}\text { Elei- } \\
\text { tos }\end{array}$ & $\begin{array}{c}\text { Candi- } \\
\text { datos }\end{array}$ & $\begin{array}{l}\text { Elei- } \\
\text { tos }\end{array}$ & $\begin{array}{c}\text { Candi- } \\
\text { datos }\end{array}$ & $\begin{array}{l}\text { Elei- } \\
\text { tos }\end{array}$ & $\begin{array}{c}\text { Candi- } \\
\text { datos }\end{array}$ & $\begin{array}{l}\text { Elei- } \\
\text { tos }\end{array}$ \\
\hline Nenhum & 15,4 & 3,1 & 17,6 & 2,4 & 21,0 & 9,1 & 16,5 & 4,5 & 18,9 & 8,4 & 18,0 & 5,8 \\
\hline Baixíssimo & 4,0 & 1,5 & 5,1 & 2,4 & 1,0 & 1,5 & 2,4 & 1,1 & 6,3 & 1,2 & 3,6 & 1,2 \\
\hline Baixo & 13,2 & 0,0 & 11,9 & 0,0 & 18,4 & 3,0 & 17,4 & 5,6 & 24,9 & 13,3 & 18,1 & 5,5 \\
\hline Médio/baixo & 9,7 & 9,2 & 10,8 & 2,4 & 7,4 & 3,0 & 9,1 & 4,5 & 20,6 & 28,9 & 11,9 & 10,8 \\
\hline Médio & 16,7 & 13,8 & 22,7 & 29,3 & 22,7 & 18,2 & 15,9 & 18,0 & 17,4 & 30,1 & 18,8 & 21,5 \\
\hline Médio/alto & 11,9 & 15,4 & 12,5 & 17,1 & 15,2 & 33,3 & 17,6 & 27,0 & 7,4 & 10,8 & 13,0 & 20,9 \\
\hline Alto & 28,2 & 55,4 & 15,9 & 36,6 & 13,3 & 30,3 & 19,1 & 34,8 & 4,3 & 7,2 & 15,2 & 31,4 \\
\hline Muito alto & 0,4 & 1,5 & 2,8 & 9,8 & 9,8 & 0,0 & 1,2 & 2,2 & 0,3 & 0,0 & 0,9 & 2,0 \\
\hline Altíssimo & 0,4 & 0,0 & 0,6 & 0,0 & 0,0 & 1,5 & 0,9 & 2,2 & 0,0 & 0,0 & 0,5 & 0,9 \\
\hline Total & 100,0 & 100,0 & 100,0 & 100,0 & 100,0 & 100,0 & 100,0 & 100,0 & 100,0 & 100,0 & 100,0 & 100,0 \\
\hline
\end{tabular}

Fonte: Banco de dados "Eleições 2006: candidatos ao Poder Legislativo no Brasil” do Núcleo de Pesquisa em Sociologia Política Brasileira-UFPR. 
datos eleitos nos pleitos de 1998 e 2002 (eleições que para o autor são de grande importância, pois marcam a transição entre dois governos de oposição). Afinado com os dados de Leôncio Rodrigues, Fernando mostra que os integrantes do PT partiam de uma base monetária bem menor do que os integrantes dos demais partidos até 2002. No entanto, nesse ano, os números já apontam para significativas mudanças e avanço patrimonial entre os candidatos do partido. Os políticos vencedores nas eleições de 1998 e 2002 apresentaram, entre as siglas mais importantes, a mais expressiva variação patrimonial em quatro anos, $83,7 \%$.

PFL, PP e PMDB são as legendas que apresentam o maior número de candidatos e eleitos com alto patrimônio. Ainda que os candidatos petistas venham apresentando avanços patrimoniais, ele ainda se destaca dos demais por ser aquele com maior número de candidatos e eleitos com nenhum, baixo e médio/baixo patrimônios. Mais de $80 \%$ de candidatos e eleitos do PT têm médio patrimônio ou menos. Em todos os demais partidos a maioria dos candidatos e eleitos possui médio patrimônio ou mais. O que foi encontrado está de acordo com a expectativa criada pelos processos de recrutamento. O processo mais inclusivo do PT seleciona e oferece oportunidade para os menos endinheirados. Já os partidos mais fechados no momento do recrutamento não abrem esse espaço.

\section{Considerações finais}

Este artigo buscou investigar o processo de seleção e o perfil dos candidatos e dos eleitos à Câmara dos Deputados à luz das eleições de 2006. Seus objetivos foram dois. Primeiro, tratou-se de examinar qual é a influência e por quais meios as lideranças partidárias buscam controlar o acesso e a composição da lista partidária dos cinco principais partidos brasileiros. Segundo, verificou-se o grau de inclusividade desses partidos, identificando-se o perfil social e ocupacional dos candidatos e dos eleitos.

Os dados revelam informações importantes a respeito da relação entre recrutamento político-partidário e controle da representação política no país. Em primeiro lugar, constatou-se que as lideranças partidárias concentram grande poder no processo de recrutamento e formação das listas de candidatos. No PP e no PFL, os dirigentes definem a lista, e nas convenções elas são apenas homologadas pelos demais filiados. No caso do PMDB e do PSDB, os líderes montam as listas que depois são votadas nas convenções. A presença das lideranças no PT o mais inclusivo deles no quesito "quem escolhe os candidatos" - também não é pequena. Ou seja, apartir da análise dos estatutos nacionais e da obserpartir da análise dos estatutos nacionais e da observação participante das convenções no estado de São Paulo, ficou claro o caráter centralizado das lideranças partidárias no processo de seleção das candidaturas.

Em segundo lugar, observou-se que entre os mecanismos utilizados pelos dirigentes partidários para garantir seu controle sobre os resultados desse processo de seleção estão o método de formação da lista por indicação e não por votação - e as estratégias eleitorais sobre o número de candidatos que irá compô-las. Outros meios identificados foram a forma de convocação para as convençôes, a possibilidade de intervenção dos diretórios de instância superior sobre as inferiores e, ainda, a criação de comissões provisórias e interventoras (no caso do PMDB).

Em terceiro lugar, verificou-se ainda que o tipo de processo de seleção - mais ou menos inclusivo - e a forma de organização da estrutura de autoridade e de oportunidades nesses partidos políticos - mais ou menos centralizada em suas lideranças - importam sobremaneira na definição das candidaturas, na medida em que influencia o perfil dos selecionados. Daí o processo de recrutamento dos partidos repercutir no perfil de candidatos e eleitos da legenda. Entre os cinco partidos analisados, dois tiveram atitudes típicas de legenda mais ou menos inclusivas. O PT é o tipo mais inclusivo dos partidos investigados, abrindo mais espaço para mulheres, pessoas de baixa escolaridade e trabalhadores manuais. Do lado oposto, aparece o PFL como o tipo menos inclusivo, abrindo pouco espaço para a diversidade. $\mathrm{O}$ componente populista fez do PP um partido mais inclusivo no que se refere à classe social dos aspirantes, ainda que tenha demonstrado um padrão de recrutamento pouco inclusivo. O PSDB e o $\mathrm{PMDB}$, respectivamente segundo e terceiro partidos na escala de inclusão/exclusão do recrutamen- 
to, apresentaram perfis de candidaturas e eleitos pertinentes com os seus procedimentos de seleção de caráter intermediário. O PSDB mostrou-se o mais inclusivo no que se refere ao sexo dos candidatos e o menos inclusivo em relação ao grau de escolaridade. Por sua vez, o PMDB demonstrou-se mais inclusivo quanto à idade e menos inclusivo no que se refere ao quesito "patrimônio".

É preciso chamar a atenção, no entanto, que há mais diferenciação entre os partidos quando comparamos o perfil de seus candidatos do que quando analisamos o perfil de quem eles elegem. Os dados sobre os recrutados confirmam a proposição de que o partido mais inclusivo no recrutamento (no caso o PT) seria também o mais inclusivo no que se refere ao resultado da composição da lista, demonstrando-se mais aberto para as diversidades da sociedade.

Os resultados sobre o perfil dos candidatos permitem ainda a demonstração de que os partidos de esquerda acolhem melhor os candidatos com menos patrimônio do que os demais, tal como encontramos em Rodrigues (2006).

Já no que se refere à análise do perfil dos eleitos, há uma maior uniformização entre os partidos. De modo geral, os homens, com grau de escolaridade e patrimônio mais altos, já políticos ou médicos, advogados, engenheiros, empresários, funcionários públicos, têm mais chances de vencer a disputa, em qualquer partido, inclusive no PT. É evidente a correlação entre patrimônio mais alto e mais chances de vitória.

Os resultados da pesquisa apontam para outra questão que merece ser estudada. Apesar de os partidos apresentarem procedimentos distintos para recrutamento e gerarem, assim, diferentes perfis de candidaturas, há uma tendência de homogeneização do perfil dos eleitos. A pergunta que se coloca é se tal padronização é fruto de uma questão cultural do eleitor - de preferir candidatos homens, com idade próxima a 50 anos, com alta escolaridade e patrimônio médio/médio alto - ou de uma maior disponibilidade de recursos de campanhas para esse segmento que, de antemão, já tende a sair vitorioso.

Por fim, cabe salientar que este trabalho trouxe evidências inéditas para que se questione o argumento da fragilidade da autoridade partidária no âmbito de sua organização, menos com a intenção de negálo do que com o objetivo de qualificá-lo a partir de estudos empíricos. Afinal os desafios para o entendimento do recrutamento político ainda são muitos, o que requer uma ampla agenda de pesquisas.

\section{Notas}

1 Dados oriundos do projeto de pesquisa "Partidos Políticos: Organização, Recrutamento Político e Representação", desenvolvido no Departamento de Ciências Sociais da Universidade Federal de São Carlos, com financiamento da Fapesp.

2 Essas dimensões analíticas foram elaboradas a partir dos trabalhos de Rahat e Hazan (2001), Billie (2001), Gallagher (1988) e Freidenberg e Lópes (2002). Todos esses estudos apresentam uma série de perguntas sobre o tema, realizadas em outros contextos que, na medida do possível, foram incorporadas nesta construção analítica para examinar o caso brasileiro.

3 Para a análise das regras eleitorais foram consultados o Código Eleitoral e a Constituição de 1988.

$4 \mathrm{Na}$ América Latina apenas a legislação eleitoral de El Salvador e Equador, até 1996, apresentam essa exigência (Freidenberg e López, 2002, p. 167).

5 Essa classificação segue orientação dos trabalhos de Rahat e Hazan (2001).

6 Sobre as convenções partidárias, ver o artigo 7, sobre o prazo, ver o artigo 8 da Lei Eleitoral de n. 9.504, de 30/9/1997.

7 Essas entrevistas foram realizadas por Braga (2008) na ocasião da pesquisa.

\section{BIBLIOGRAFIA}

ÁLVARES, Maria Luzia Miranda. (2006), "Determinantes da seleção de candidaturas aos cargos parlamentares e regras estatutárias na formação do selecionador brasileiro, nas eleições de 2002". Trabalho apresentado no V Encontro da Associação Brasileira de Ciência Política, UFMG, Belo Horizonte.

BILLIE, Lars. (2001), "Democratizing a democratic procedure: myth or reality?". Party Politics, 7 (3): 363-380.

BRAGA, Maria do Socorro S. (2006), O processo partidário-eleitoral brasileiro: padrões de competição politica 1982-2002. São Paulo, Humanitas/Fapesp. 
. (2008), “Organizações partidárias e seleção de candidatos no estado de São Paulo". Opinião Pública, 14 (2): 454-485.

BRAGA, Maria do Socorro S. \& PRAÇA, S. (2007), "Recrutamento partidário: seleção de candidatos à Câmara dos Vereadores paulistana”, in Maria do Socorro Braga e Maria D’Álva Kinzo (orgs.), Eleitores e representação partidária no Brasil, São Paulo, Humanitas/CnPQ.

BUTLER, David; PENNIMAN, Howard R. \& RANNEY, Austin (eds.). (1981), Democracy at the polls: a comparative study of competitive national elections. Washington, DC, American Enterprise Institute for Public Policy Research.

CAREY, John M. \& SHUGART, Matthew S. (1995), "Incentives to cultivate a personal vote: a rank ordering of electoral formulas". Electoral Studies, 14 (4): 417-439.

DUVERGER, Maurice. (1970), Os partidos políticos. São Paulo, Zahar.

EPSTEIN, Leon. (1982), Political parties in Western democracies. 2 ed. New Brunswick/Londres, Transaction Books.

FREIDENBERG, Flávia \& LOPES, Francisco S. (2002), "Como se escolhe um candidato a presidente? Regras e práticas nos partidos políticos da América Latina”. Opinião Púbica, 8: 158188.

GALLAGHER, Michael \& MARSH, Michael (eds.). (1988), Candidate selection in comparative perspective: the secret garden of politics. Londres, Sage.

GUARNIERI, Fernando. (2004), Partidos, seleção de candidatos e comportamento político. São Paulo, dissertação de mestrado, DCP-USP (mimeo.).

HOPKIN, Jonathan. (2002), "The emergence and convergence of the cartel party: parties, State and economy in Southern Europe". Paper prepared for panel on "The New Political Economy of European Political Parties" at the Conference of Europeanists, Chicago.

KATZ, Richard S. (2001), "The problem of candidate selection and models of party democracy". Political Studies, 7 (3): 277-296.

KATZ, Richard S. \& MAIR, Peter. (1995), "Changing models of party organization and party democracy: the emergence of the cartel party". Party Politics, 1: 5-28.
KEY, Valdimer Orlando. (1964), Politics, parties and pressure groups. Nova York, Crowell.

KIRCHERAIMER, Otto. (1966), "The transformation of the Western European party systems", in J. Lapalombara e M. Weiner (eds.), Political parties and political development, Princeton, Princeton University Press.

KOOLE, Rudd. (1996), "Cadre, catch-all or cartel? A comment on the notion of the cartel party". Party Politics, 2 (4): 507-523.

MAINWARING, Scott. (1991), "Políticos, partidos e sistemas eleitorais: o Brasil numa perspectiva comparada". Novos Estudos, 29: 34-58.

. (1992), "Brazilian party underdevelopment in comparative perspective". Political Science Quarterly, 107 (4): 677-707.

. (1999), Rethinking party systems in the third wave of democratization: the case of Brazil. Stanford, Stanford University Press. - (2001), Sistemas partidários em novas democracias: o caso do Brasil. Porto Alegre/Rio de Janeiro, Mercado Aberto/FGV.

MAINWARING, Scott \& SCULLY, T. R. (eds.). (1995), Building democratic institutions: party systems in Latin America. Stanford, Stanford University Press.

MAIR, Peter \& KATZ, Richard. (1990), How paties organize. Cambridge, Cambridge University Press.

MAIR, Peter \& BIEZEN, Ingrid van. (2001), "Party membership in twenty European democracies, 1980-2000". Party Politics, 7 (1): 5-21.

NORRIS, Pippa. \& LOVENDUSKI, Joni. (1995), Political recruitment: gender: race and class in the British Parliament. Cambridge, Cambridge University Press.

PANEBIANCO, Angelo. (1992), Modelos de partidos. Madri, Fundo de Cultura Económica.

PENNINGS, Paul \& HAZAN, Reuven Y. (2001), "Democratizing candidate method selection: causes and consequences". Party Politics, 7 (3): 267-275.

RAHAT, Gideon \& HAZAN, Reuven Y. (2001), "Candidate selection methods an analytical framework". Political Studies, 7 (3): 297-322.

RANNEY, A. (1965), Pathways to Parliament: candidate selection in Britain. Madison, University of Wisconsin Press. 
RODRIGUES, Fernando. (2006), Políticos do Brasil. São Paulo, Publifolha.

RODRIGUES, Leôncio Martins. (2002), Partidos, ideologia e composição social: um estudo das bancadas partidárias na Câmara dos Deputados. São Paulo, Edusp.

- (2006), Mudanças na classe política brasileira. São Paulo, Publifolha.

SANTOS, André Marenco. (2000), Não se fažem mais oligarquias como antigamente: recrutamento parlamentar, experiência política e vínculos partidários entre deputados brasileiros (1946-1998). Porto Alegre, tese de doutorado, UFRGS.

. (2005), "Listas eleitorais e competição partidária em perspectiva comparada”. Trabalho apresentado no XXIX Encontro Anual da Anpocs, 25/29 out. (mimeo.).

SCHATTSCHNEIDER, Elmer E. (1941), Party government. Nova York/Holt, Rinehart and Winston.

SARTORI, Giovanni. (1982), Partidos politicos e sistemas partidários. Brasília, Editora da UnB. (1986), "The influence of electoral systems: faulty laws or faulty method?", in Bernard Gofman e Arend Lijphart, Electoral laws and their political consequences, New York, Aghaton Press.

SCHLESINGER, Joseph A. (1991), Political parties and the winning of office. Ann Arbor, University of Michigan Press. 


\section{RECRUTAMENTO E PERFIL DOS CANDIDATOS E DOS ELEITOS À CÂMARA DOS DEPUTADOS NAS ELEIÇÕES DE 2006}

\author{
Maria do Socorro Sousa Braga, \\ Luciana Fernandes Veiga e \\ Angel Miríade
}

Palavras-chave: Partidos políticos; Recrutamento político: Eleição legislativa; Seleção de candidatos; Democracia representativa.

Este artigo investiga o papel dos principais partidos políticos brasileiros no processo de seleção dos candidatos, bem como o perfil dos eleitos à Câmara dos Deputados nas eleições de 2006. Para isso as autoras sustentam que há uma relação entre a estrutura das organizações partidárias e o controle da representação político-partidária no Brasil. Concluem que existem diferenças entre o perfil dos candidatos selecionados pelas respectivas legendas, relacionadas com as diferenças em seus procedimentos de recrutamento. No entanto, tais diversidades são reduzidas após a escolha dos eleitores. As diferenças expressas nos perfis dos selecionados pelos partidos não se mantêm após o processo eleitoral, quando há uma tendência a um padrão mais uniforme entre os eleitos.

\section{RECRUITMENT AND PROFILE OF CANDIDATES AND THE ELECTED TO THE CHAMBER OF DEPUTIES IN THE ELECTIONS OF 2006}

\section{Maria do Socorro Sousa Braga, Luciana Fernandes Veiga and Angel Miríade}

Keywords: Political parties; Political recruitment; Election to Chamber of Deputies; Selection process of candidates; Representative democracy.

The paper examines the function of the major Brazilian political parties in the selection process of candidates to the Chamber of Deputies. The authors argue that there is a relationship between the structure of party organizations and the control of political-party representation in Brazil, expressed in this article in the selection of candidates. They conclude that there are differences between the profiles of the candidates selected by their parties, which are related to differences in their recruitment procedures. However, such differences are reduced after the electoral process. The differences expressed in the profiles of the candidates selected by the parties do not remain after the elections, when there is a trend to a more uniform standard among the candidates elected.
RECRUTEMENT ET PROFIL DES CANDIDATS ET DES ÉLUS À LA CHAMBRE DES DÉPUTÉS AUX ÉLECTIONS DE 2006

\author{
Maria do Socorro Sousa Braga, \\ Luciana Fernandes Veiga et \\ Angel Miríade
}

Mots-clés: Partis politiques; Recrutement politique; Élections législatives; Sélection des candidats; Démocratie representative.

Cet article présente une analyse du rôle des principaux partis politiques au Brésil dans le processus de sélection des candidats et le profil des élus à la Chambre des Députés aux élections de 2006. Les auteurs défendent l'existence d'un rapport entre la structure des partis politiques et le contrôle de la représentation politique de ces partis au Brésil. Elles concluent qu'il existe des différences entre le profil des candidats sélectionnés par leurs respectives légendes, et que ces différences sont liées aux procédures de recrutement politique. Néanmoins, de telles diversités sont réduites suite au choix des électeurs. Les différences exprimées dans les profils choisis par les partis ne se maintiennent pas postérieurement au processus électoral, moment où apparaît une tendance à un modèle plus uniforme entre les élus. 